\title{
In the Service of Pharaoh? The United States and the Deployment of Korean Troops in Vietnam, 1965-1968
}

\author{
NICHOLAS EVAN SARANTAKES
}

The author is a memu rof the history department at Texas A $\mathrm{G}$ M L niversity-Commerce.

In 1965 and 1966 the Republic of Korea (ROK) sent two infantry divisions and a few other support units to serve in the Republic of Vietnam $(R V N)$. This decision reflected the strength of L.S.-Korean relations. The ROK wholeheartedly supported the U.S. initiative in Vietnam in an effort to keep American troops on the Korean peninsula. Even so, the South Koreans refused to let U.S. officials take them for granted, manifesting their independence in two wavs: First, the Koreans insisted on high-level consultation and requests from either the L.S. President or Vice-President, although they would negotiate with individuals as low as the secretaries of State or Defense. Second, this L'.S. ally demanded and received substantial compensation for the assignment of its soldiers. Koreans fought in Vietnam because it served both the political needs of the ROK government and the security requirements of the Republic.

Few works in English address the service of Korean soldiers in Vietnam. The novelists Hwang Sog-yong and An Chong-hyo, both of whom served in Vietnam, have had their fictional accounts translated into English.' In his recent study of modern

The author wishes to thank Mike Burns and Mitch Lerner for their comments on earlier drafts, and Second I ieutenant Andrew Sarantakes and Mi-Sook Sarantakes for their translation work.

1. Hwang Sog-yong. The Shadow of Arms (Ithaca, N.Y., 1994): An Chong-hyo, White Badge: A Novel of Korrea (New York, 1989). 
Korea, Bruce Cumings mentions the deploment of ROK units brictly but only within the context of South Korean efforts to obtain foreign capital for industrial development." Donald Stone Macdonald devotes less than wo pages to the subject and its background in his study of postwar L.S.-Korean relations, but this work examines only the first twents vears of the bilateral partnership. ${ }^{3}$ The ROK presence in Vietnam is mentioned only in passing in two collective books that explore the first hundred vears of bilateral relations. ${ }^{4}$

Robert M. Blackburn's comparative study of American allies in Vietnam offers more substantial treatment in a chapter on korea. He argues that South Korean soldiers served in Vietnam as mercenaries." Even with an expansive definition of a mercenary as a soldier who fights for pay in or for a country other than his own, the korean troops in Vietnam do not meet this criterion. These soldiers served in ROK Armv divisions, which were never under the operational control of an American general. ". More importantly, Blackburn's mercenary thesis does not explain the policies or reasons for the deployment of $\mathrm{Ko}$ rean units. It is difficult to accept the assumption implicit in Blackburn's argument that the Republic of Korea had no interests in Vietnam other than making monev. To be sure. Blackburn mentions briefly that South Korea acted in its own national interests, but he never develops or explains these concens.'

The korean presence in Vietnam deserves a new examination for several reasons. First, important documents have recently been declassified. Second, the ROK contingent was the largest arnong American allies, amounting at its peati to a force

2. Bruce Cumings, Komea's Place in the Sun: A Modern Historn (Now Ioth. 1997). 321.

3. Donald Stone Vacdonald, L.S.-Korean Relations from Liberahom to telfReliance: The Turent) Year Record (Boulder, Colo.. 1992), 108-110.

4. Yur-Bok Lee and Wayno Pallerson, eds. One Ilundred Years of KompenAmerican Relations, 1982-1482 (Tuscaloosa, Ha., i986): Tae-Hwan Kwak, John Chat. Soon Sung Cho, and Shannon Mccune, eds., LS.-Korean Relations, 1852 - 1982 (Scoul, 1982).

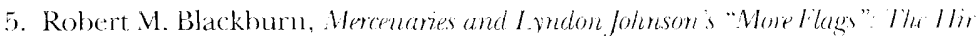
ing of Korean, Filipino, and Thai Soldiers in the Vietnam War (jeflorson. ….. 1944).

6. Transcript, n.d., document \#45, varch 31 speech file, vol. T. box 49. VSe [National Security Council | Histories. Nauonal Security file, Lyndon Baines fohnson Presidential Library, Austin, Texas (hereafier referred to as LBJ L ibrary.

7. Blackburn, Mercenaries and L, hudon fohnsm is ". More Llags". 36. 
of just over 50,000 men. The contributions of the other allies seem almost coken in comparison; the combined strength of the other four allied expeditions never equaled half the size of the ROK force. Finally and perhaps most importantly, the deployment of such large numbers of men is best understood within the framework of Northeast Asian affairs and American bilateral relations with the Republic of Korea, rather than as part of a multilateral presence in Vieunam. In this light, the combat duty of Korean troops in Southeast Asia served the needs of both the Lnited States and South Korea.

In 1965 the major issue in Vortheast Asia was the treaty between Japan and Soluth horea that provided for diplomatic recognition and an exchange of ambassadors. Although the United States was not a formal parry to this compact, it had used its intluence for the treatr. Both signatorics agreed to conduct the negotiations only after President Lundom fohnson applied pressure through his ambassadors in Seoul and Tokvo. The United States had long worried about conflicts between these two vital Anerican allies in the northeastern corner of Asia. Koreans still resented Japan's colonial rule of the peninsula, while the Japanese historically considered themselves superior to their Asian neighbors.

Ratification of the treaty was extremely controversial in South korea. Even though President Park Chung-hee had come to power in a military coup, he needed the approval of the National Assembly to ratify the treaty. Opponents claimed that the accord was the first step in a second American betraval of Korea to Japan. Koreans so despised the Japanese that Park faced serious difficulties in setting the agreement ratified, despite the authoritarian nature of his regime. ${ }^{10}$ Kim Hyun-chul, the

8. The only toreign contingern with more than 10,000 men in Vienam was Thailand with 11.570 in 1969 and 1970 . Australia had $7,670 \mathrm{~m} \mathrm{1969}$. New Zealand had 552 in 1969, and the Philippines had 2,060 in 1966. Shelby L. Statnton, Vietnam. Order of Batle illashington, D.C.. 1981), 272-273. 333; tor slightly differen numbers. see Blackburn, Mercerumes and Lyndon fohmson s" "More Flags". 158.

9. Rober komer to lendon Johuson. Julv 31 . 1964, and VeGeorge Bund 10 fohmon. July 29, 1964, Korea memos, vel. 2, box 254, Korea Counurv File, Nalional Securite File, 1.13 1 h ibrant.

10. Chesun /lbo, April 17, 18, 1965. Wher Japan colonized Korea in 1905. the latler had a treaty with the Lnited States that many Koreans considered a security alliance. Koreans fel be:raved, because the administration of Theodore Rooseveh did nothing to stop the Japanese. John F.dward Wilz, "Did the Lnited States Betray 
Korean ambassador in Washington, made this worry clear to Undersecretary of State George Ball. ${ }^{11}$ To still public concern about their ally, Park needed to keep Korea as close to the United States as possible. In order to do this, he needed to keep American troops on the peninsula.

The U.S. Department of Defense, however, wanted to reduce the number of Americans stationed in Korea. Military planners began studying the issue during the administration of John F. Kennedy. Then, the United States had two infantry divisions on the peninsula, and Secretary of Defense Robert McNamara told Johnson that the new air assault divisions of the U.S. Army were much more mobile and deployable than traditional infantry and could do the work of the two units stationed in Korea. Reducing the American presence on the peninsula would also improve America's balance of pavments. Robert Komer of the National Security Council (NSC), who was soon to become Johnson's National Security Adviser, agreed. "We're so over insured in Korea compared to so many other places that we'd better bite the bullet while the time is ripe," he told McGeorge Bundy, the current National Security Adviser. ${ }^{12}$

These plans to reduce the American presence in Korea promised to complicate matters for Park, but the U.S. "Free World Assistance Program" seemed to offer a way to strengthen ties with the United States. This initiative aimed to legitimize the struggle in Vietnam by getting other nations to establish assistance programs for the benefit of South Vietnam. As Blackburn

Korea in 1905?" Pacific Historical Review, 54 (1985), 243-270. Korean fear of another American betrayal is a constant theme in postwar L..S.-Korean relations. In a letter to President Harry S Truman, Syngman Rhee, the future president of the Republic of Korea, stated that Korea was "sold to Japan" in 1905. Rhee to Truman. Mav 15, 1945, L.S. Dept. of State, Foreign Relatums of the Lnited States, 1945 (9 vols., Washington, D.C., 1967-1969), 6: 1028-1029. Rhee repeated these fears in 1949. Memorandum of Conversation, by the Ambassador in Korea (John Muccio), May 2. 1949, in U.S. Dept. of State, Foreign Relations of the Lnited States, 1949 (9 vols., Washington, D.C.. 1974-1977), 7: 1004. James (. Thompson, Jr., a National Security Council staff member, warned Johnson about Korean sentiment toward the treaty prior to an Oval Office mecting Johnson had with Park Chung-hee. Thompson to Johnson, May 17, 1965, Park briefing book file, box 256, Korea Country File, Vational Security File, LBJ Library.

11. Memorandum of Conversation, March 11, 1965, Korea memos, vol. 2. box 254, ibid.

12. Robert McNamara to Johnson, Nov, 25, 196.3, and Komer 10. Mc ieorge Bundy, Dec. 9, 1963, filed by L.BJ Library staff, box 256, ibrd. 
notes, "The most impontant tactor was that an allied naton sent aid, any aid. wo South Vieman, because by so doing that countrr. ipso facto showed it supported the L.S. position there." 13 Even so, the Lnited States fomd most nations reluctant to contribute. On fune 15. 1964. Secretary of State Dean Rusk sent Jomson a status teport on the program. The Lnited States had approached nineteen allies, but the responses were vague and limited largek to small amounts of inedical assistance. "There is still not enough progress." Rusk added in a hand-written note on the cover memo to the report. ${ }^{14}$

The Republic ol Kored represented an important excepton to this lackluster response. "The Koreans have not only been willing to send miliary help to Vienam but are even anxious to do so. provided we pay the bill," Rusk informed Johnson in another report. "The principal problem has been finding things for them to do." Sending RoK Arme officers to V'ietnam as advisers was a possibility, but langaage barriers posed a problem, since fen Korean! officers spoke English. (Rusk never explained why Koreans would need to speak English while serving with the South Viemantese Amm ). ${ }^{13}$

Despite Korea 's willingness to send its military to Vieunam, many individuals in the L.s. government questioned the wisdom of aceepling the offer. Several ambassadors waned that the deployment of Korean troops would have negative repercussions. Adlai Sievenson, ambassador to the Lnited Vations, cautioned that the move "woukd open $/$ the $/$ ROK and L .S. io attack on numerous grounds. not least of which would be long-

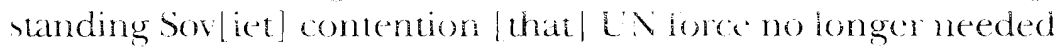
in South Korea." Ambassador Jerauld Wright, in the L.S. cmbass in Taipei, observed that Chiang Kai-shek would also want wo send troops wo fietnam in an effort we expand the war ino an ataack on the Peoples Republic of China such a development was not in Anerican interests, and the Lnited states should be prepared to explain to Chiang whe Koredn troops were acceptable while his were not. ${ }^{16}$

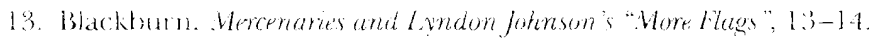

14. Dean kusk 16 Johnson, fune 15, 1964, Vicham memos, vol. 12, box 5.

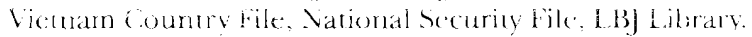

15. Ibid, Rusk o Johnson. De. 11. 1964. Vienam memos, vol. 15. hox 11, ibid.

16. Adlai Stevenson of kusk, March 20. 1964. and Jerauld Wright wo Rusk,

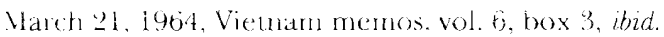


Opposition also came from the L.S. military. During the Korean War, the differing supply sustems and tactical doctrines of the various allied countries had created problems that often outweighed the advantages of additional troops. Mans American officers had profound doubts about the caliber of the $\mathrm{ROK}$ Army, wondering if Korean soldiers would fight or run. ${ }^{17}$ A powerful counter-view came from the L.S. embassv in Saigon. Henry Cabot Lodge, the American ambassador to South Vietnam, cabled, "I understand that the ROK has well qualified personnel for the type of work where our men are getting killed and wounded. Why not use a few of them here?" When presented in this manner, it became difficult to argue against the use of foreign troops, and the idea gained momentum in Washington. ${ }^{18}$

Initially, the Johnson administration compromised, welcoming Korean advisers and medical units, but not combat forces. Rusk informed his ambassador in Seoul, Winthrop Brown, that the "U.S. itself has not been asked by [the] (i[overnment of] $V$ [iet] $\mathrm{N}$ [am] to introduce combat ground force units into Viet Nam. We would not consider it appropriate or suitable under current circumstances of guerrilla warfare to put fighting ground force troops into this situation." ${ }^{19}$

At the end of 1964 the U.S. government decided to seek a larger Korean military contingent in Vietnam. Undersecretary of State Ball directed Ambassador Brown to deliver an oral message to Park on the personal behalf of Lyndon Johnson, requesting a service and support unit, perhaps an engineering outfit to repair a number of roads and bridges in central Vietnam. "Foreign combat units would not be desirable," Ball informed Brown. "It is not that kind of war." ${ }^{20}$ Park responded immediately, offering two combat divisions "whenever they were

17. General Charles H. Bonesteel ill oral history interview Senior officers Debriefing Program (L.S. Army Militarv History Institute, Cartisle Barracks. Carlisle, Pennsylvania), 365; William 11. Sullivan to Mc(xeorge Bundy, June 24. 1964, Vietnam memos, vol. 12, box 5; George Ball to Johnson, Dec. 14, 1961, folder "Viemam memos, vol. 23 (2 of 2)," hox 11, Vietnam Countrv File. Vational Security Gile, [.B] Library.

18. Henry Cabot Lodge to Rusk, May 9, 1964, Ball to Winthrop Brown, May 12, 1964, Vietnam memos, vol. 8. box 4, ibid.; Sullivan to . Veceorge Bundy, June 24, 1964, Vietnam memos, vol. 12, box 5, ibid.

19. Rusk to Brown, July 3. 1964, Vietram memos, vol. 13, box 6, ibid.

20. Ball to Brown, Dec. 17, 1964, Korea cables, vol. 2, box 254, Korea Country File, National Security File, LBJ Library. 
nceded," but Brown told him it was not a conventiond war. This rejection did nothing to dampen interes in Seoul, and a lew days later, the ROK Joint Chicts offered to send several enginecring and transportation units, waling 1,022 personnel.21

Only a news leak marred this agreement. The Korean constitution required the Vational Assembly approwal for the overseas assignment ot any ROK armed forces. Seoul newspapers learned of the agreement after the Joint Chiefs bricfed the legislators. Vew's of the deployment became public belore anv actual Vietramest request. "Cat clearly ou of bag," Brown cabled back to Washington." Although this leak might have wounded Vietnamese pride, it did litele 10 jeopardize approval of the agreement.

A few months later. the Vietnamese made up for this slight. showing their independence from their American patrons. Political stability in South Vietnam deterionated rapidly in the spring of 1965 as a confusing series of coups and councer-coups occurred. Several units in the Armv of the Republic of Vietnam (ARVV) had desertion rates of 50 percent. The Vietcong began a series of offensive operations, decimating the ARVN units that bothered to fight. With these events as a backdrop, South Vietnam, without informing the Cnited States, sent a formal request to the Republic of Korea asking for militar assistance in the form of combat troops. Rusk thought the request for troops would complicate ratification of the ROK-japan treaty. In order to contain what he thought was a potentially disruptive issue, he instructed Brown to begin talks with Park about sending a regimental combat team, rather than a division. ${ }^{23}$

The drastic events of the spring forced the fohnson administration to consider the introduction of $L$.s. ground combat units. Ceneral William Westmoreland, the commander of the Militarv tssistance Command in Saigon. wanted to change

21. MeGeorge Burndy and Cheser Cooper to Juhnson, ber. 22. 1964, Vie -

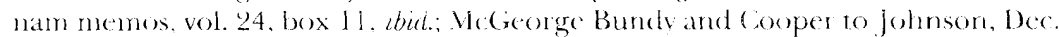
28. 1964, Vietnan mentos, vol. 25, box 12. Vieman Country File, Vatronal becuritv File, ibid.

22. Brown w Rusk, Dee. 99, 1964, Vïenam memos, vol. 24. box 11, ibid.

23. George C. Herring, America's Longest War: The linted States and Vietnam, 1950-1975 (New York. 1986), 136-137; Rusk w Brown, April 14, 1965, Korea cables, vol. 2, box 254, and Rusk to Johnson, May 17. 1965, Park Briefing Book. box 256. Korea Country File, Nauonal Secuniv File, LBI L ibrary. 
the mission of two marine battalions then stationed in Vietnam from base security to offensive combat operations. The Joint Chiefs of Staff disagreed. The Chiefs told Johuson that one marine and one infantry division were required to prevent defeat. On April 1, 1965, minutes after telling reporters at a press conference that he did not contemplate making any "far-reaching" change in L.S. policy, Johnson did just that, walking to the other end of the White House, meeting with his foreign policy advisers, and authorizing the new mission for the two marine battalions. ${ }^{24}$

The President's decision did not sit well with Maxwell Tavlor, the L.S. ambassador in Saigon. He feared the Vietnamese would see the introduction of L'S. troops as a neocolonial act. The presence of L.S. soldiers would allow the ARVN to abdicate its responsibilities, making South Vietnam weaker. Taylor could thwart the introduction of American troops simply by refusing to clear the issue with the South Viemamese government. Because of Taylor's opposition, Johnson postponed the deployment until his kev militarv leaders could settle their differences. McNamara, Assistan Secretary of State William Bundy, Assistant Secretary of Defense John McNaughton, and General Earle Wheeler, chairman of the Joint Chiefs of Staff, flew to Honolulu to meet with Taylor, Westmoreland, and Admiral L.S. Grant Sharp, the Commander-in-Chief, Pacific. This group met on April 20, in the War Room of Pacific Command Headquarters, overlooking Pearl Harbor. The uniformed military leadership in the room favored the two-division deplowment. As a former chairman of the Joint Chiefs, however, Taylor had the military credentials and East Asian expertise from pre-World War II service in China and Japan to make an informed argument against this proposal. Bundy, McNamara, and Mc Naughton were prepared to vield. All three realized that the Chiefs had more political leverage during time of war and that they would have to accede to their demands. The civilians agreed to assign two

24. American torces in Viemam at the: lime were cither Air Foret tlight units or militarv advisers. Although nol considered combat tronps, militarv advisers often suffered casualties and fatalities when ARV N unts engaged the entemy. Most of the American advisers serving with ARVN infantry units were Creen Berets. Brian VanDe.Mark, Into the Quagmire: Lyndon Johnson and the Escalation of the Vietram War (New York, 1991), 105-106, 109. 
army and three marine battalions to combat duty in Vietnam. The Chiefs were also permitted to make logistical preparations for the introduction of two divisions later that summer. ${ }^{25}$

A month later, on May 17, Johnson met with Park at the White House. Just before the reception ceremonies, James C. Thompson, a National Security Council (NSC) staff member, sent the President a memo warning him that Park wanted "to use the question of further troops in order to pry major additional concessions out of the U.S. Government." According to Thompson, Park would probably raise the issue of U.S. efforts to force Korea into a closer relationship with Japan and continued American support of the ROK military: ${ }^{26}$

This advice was sound. Earlier American efforts to reduce aid and troop levels on the Korean peninsula had troubled ROK leaders. Even though South Korea lacked the economic strength to support a force of its size, the Republic of Korea nevertheless had $600,000 \mathrm{men}$ in uniform in 1965. The United States underwrote the Korean military primarily through the Mutual Assistance Program (MAP), which paid for military supplies that the Koreans could not afford on their own. Through the early 1960s American officials made sporadic and unsuccessful efforts to reduce the MAP levels sent to the peninsula. The possibility of a MAP cut worried the Koreans, who still feared another abandonment to the Japanese. ${ }^{27}$

At 5:00 p.m., the two presidents arrived at the Oval Office for some serious and hard diplomatic bartering. Park sat stiffly on the sofa, relaxing after smoking a cigarette. The conversation stopped and started as the translators took notes and explained to each president what his counterpart was saring. ${ }^{2 x}$ As the host, Johnson started the conversation, stating that he had no plans to reduce American troop strength on the peninsula. If the

25. Herring, America's Longest War, 130; VanDeNark. Into the Quagmire. $125-127$.

26. Thompson to Johnsor, May 17, 1965, Park Briefing Book. hox 256. kirrea Country File, National security File, LBJ Librarv: Contact Sheel A479. A475, Phose Contac Book, 05 16 65-05 18 65. Audio Visual Archives, ibid.

27. Briefing Paper: "Korcan Fore Levels and the WAP", May 11. 1965, Park Briefing Book, box 256 , Kowea Country File. National Security File, ibid.

28. Memorandum of Conversation, Nav 17, 1965, Korea memos, wol. 12, box 254, Korea Country File, ibid.; Contact Sheet A470, A475, Photo Contact Book. $0516 / 65-0518 / 65$, Audio Visual Archives. ibid. 
United States ever developed such plans, it would do so only after consulting with the Korean government. Johnson then steered the conversation to the topic of Korean security, tying Park's interest in a continued U.S. presence to his own concern about Vietnam. He told Park that as long as Korean soldiers were in Southeast Asia, there would be no reduction in L.S. strength on the peninsula. Johnson then asked his guest for more troops but said nothing about MAP levels. Park hedged, saying the matter would have to be studied at greater length. He was careful to add that he personally thought the Republic of Korea could and would provide additional troops to the anticommunist effort in Vietnam. From his point of view, the American presence in Southeast Asia was a righteous cause. Johnson pressed on, asking again for an ROK Army division. Park refused to give an answer, saying that until his government studied the issue further, he could make no commitment, but he thought well of the idea. He was subtly telling his host that Korea would send the troops only when his country had an agreement in its favor on all the related economic details. This response was too ambiguous for Johnson, and he continued his push. He reassured Park twice that the United States would keep its troops in Korea and continue to supply aid. Park looked at his host dubiously. With an expression of weary resignation. Johnson repeated two more times his desire for a Korean division. When the meeting ended, Park had outplayed a master of the political deal at his own game. ${ }^{29}$

The presidents, accompanied by their staffs, met again the next day for a similar exchange. This time Park raised the issue of MAP transfers directly. Johnson said he understood Park's concern but that the appropriations level for military aid remained unresolved in Congress. Park politely told Johnson that ROK armed forces were prepared to fight communism anywhere it appeared-as long as they had the required American assistance. He thus neatly tied MAP levels to the deplorment of Korean troops. ${ }^{30}$ Park was polite but firm in his dealings with his American counterpart. Although Korea would assist the United

29. Ibid.

30. Memorandum of Conversation, Mav 18, 1965, Korea memos, vol. 2, box 254, Korea Country File, National Security File, ibid. 
States in Vietnam, that support could not be taken for granted. Park beat Johnson badly in their meetings.

Follow-up negotiations in Seoul were equally one-sided. Korean diplomats controlled the agenda and made the proposals, while the Americans responded as best thev could. The Koreans began the negotiations with their ideal objectives. In his study, Blackburn approvingly quotes General Dwight E. Beach's characterization of the Korean requests as a "wish list." He contends that these requests prove that Korean interest in troop deplovment was financial, thus making the soldiers South Korea eventually sent to Vietnam mercenaries. The problem with this assessment is that Blackburn bases it on a misinterpretation of the evidence. The proposals were just an opening move and clearly allowed for future compromise and agreement. There was never any concern that Korea would refuse troops to Vietnam if its terms were not met. Ambassador Brown made this clear in a cable to the State Department. "There has never been any suggestion by the President or the Pri[me] Min [ister] of any bargaining in connection with the despatch of a division," the diplomat wrote. He did add, though, that there was some pressure on the matter in the National Assemblv: ${ }^{31}$

The Lnited States eventually acceded to all but one request because the American ambassador in Seoul worried about and misread Korean politics. The United States was making heavy demands on Korea in addition to the controversial treaty with Japan, and Brown simply could not accept Park's assurances that a troop deplovment would make it easier to ratify the Japanese treaty. "Korea, a small country bordering on the communist world, will be in actual combat in one of the most active areas of RVN against communist forces. It will have provided ... substantially greater combat manpower than any other free world country great or small except the United States. This is a decision of great import for any country to make," the ambassador stated in a cable back to the State Department. "But, it is also a cold fact that Korea does not have to do this, that it does involve Korea in some additional risks." 32

31. Blackburn, Mercenaries and Lyndon Johnson's "More Flags", 49; Brown to Rusk, July 29, 1965. Korea cables, vol. 2, box 254, Korea Country File, National Security File, LBJ Library.

32. Brown to Rusk, July 10, 1965, Brown to Maxwell Taylor, June 7, 1965, ibid. 
Brown feared that the deplovment could get caught up in the controversy surrounding the settlement with Japan, jeopardizing both agreements. With approval from Washington, he decided to accept the korean position. The only request the Americans refused was a 75 percent pav hike for the ROK military. Brown privately informed Park of the U.S. concessions, ending the negotiations. "We have now," the ambassador reported, "given him our maximum political ammunition." The United States acceded to an agreement that addressed fourteen points in four different areas. First, and likely foremost to the Koreans, was the issue of troop levels in Korea. The Lnited States agreed to make no force reduction without prior consultation and promised that American actions in Vietnam would not jeopardize the security of Korea. Military assistance was a second category. The United States promised to increase MAP levels by $\$ 7$ million in 1966; suspended scheduled MAP transfers for 1966-1967; agreed to provide all logistical, transportation, and supply requirements for ROK troops in Vietnam; initiated a program to modernize military equipment: and arranged to pay overseas per diem for all ROK military personnel in Vietnam. The third area was economic procurement. The United States agreed to buy supplies for Vietnam from South Korean suppliers and to hire Korean construction workers and firms for projects in Vietnam. It also agreed to provide support for social welfare projects. Specifically, Americans would fund economic development projects; provide a $\$ 150$ million development loan; pay welfare relief for needy Koreans; maintain or increase the number and amount of training program grants; and increase the export of American foodstuffs. ${ }^{33}$

The crisis that Brown had feared never developed, at least on the issue of sending a division to Vietnam. The National Assembly approved the deployment quickls. The ratification of the settlement treaty with Japan proved more contentious. Angry words were thrown about in Seoul, and all members of the opposition resigned their seats in the National Assembly rather than witness the ratification. This act forced Park's political party

33. Blackburn, Mercenuries and Lyndon Johnsonis "Wore Flags". 50; Brown to Rusk, July 29, 1965, Korea cables, vol. 2, box 254. Kored Country File. Narional Securiry File, LB] Library. 
to bear sole responsibility for the agreement. Even though a majority of the Korean public opposed it, Park survived the storm. He still had the solid support of the Korean Central Intelligence Agency, an internal security force, and the acquiescence of the army. 34

While Koreans wrestled over the approval of both agreements, Lyndon Johnson finalized a decision to send L'S. combat troops to Vietnam, which he announced on July 28, 1965. ${ }^{35}$ At this same time the United States decided to follow up on Park's standing offer and requested the service of a second division. Elements of the Capital Division were still in transit to Vietnam from Korea when Ambassador Kim met with William Bundy and asked if the Lnited States intended to solicit the service of another unit. Kim said his military attachés had learned that the issue was under active consideration in the Pentagon. The Lnited States would probably make another request, Bundy replied, but the decision was stili under discussion and no final decision had been reached. When it was appropriate, the issue would be discussed personally with Park. ${ }^{36}$

The Korean embassy had done a good job of detecting American interest in a second division but was less successful at uncovering the nature of the debate within the L'S. government. Representatives of both the State and Defense departments wanted another Korean division in Vietnam, but they disagreed strongly on how to achieve that goal. McNamara wanted to condition the authorization of three pending loans on the deplorment of a second division, while the State Department opposed any such connection. The President had publicly promised Park the loans in May, and they were already part of a quid pro quo for ratification of the Japanese setulement treaty. ${ }^{37}$

Such conditions seemed unnecessary when negotiations for the second division began in Seoul. Prime Ninister Chong Ilkwon had lunch with Brown on December 22 and told him that Park and Minister of National Defense Kim were prepared to

34. Chesun Ilbo, June 20. 20, July 23, Aug. 1․ 15, 1965.

35. VanDe.Mark, Into the Quagmire, $21 \mathrm{i}$ : Blackburn, Mercenaries and I mdon Johnson's "More Flags", 51-52.

36. Memorandum of Conversation, Dec. 9. 1965, Korea cables. vol. 3. box 255, Korea Country File, National Security File, LBJ I ibrary.

37. Francis M. Bator w Vickeorge Bundy, Dec 29. 1965. thid. 
send a second ROK Army division. The only problems would be timing and the domestic political reaction. The Koreans were hesitant to start negotiations so soon alter the deplowment of the Capital Division. As a result, Chong said that, for appearances, it was imperative that a high-ranking American, either VcNamara or Rusk, visit Seoul to consult with Park before the issue became public. 38

Rusk and McNamala were too busv to do the work of an ambassador. Vice-President Hubert H. Humphrey, however, had the time and held high office, if minimal power. In earl 1966 Johnson sent Humphrey on a world tour to pursue the possibility of a negotiated end to the Vietnam War, but his risit to Seoul had a different purpose. Humphrey s mission was to give the Koreans the high-level consultation ther desired and to convince Park and others in the govermment that the deteriorating situation in Vietnam demanded prompt action. His meeting in Seoul went well. He made several reports on the results of his trip. In a memo to Johnson, he stated, "President Park is anxious to be of greater help in Vietnam." Humphrey also noted, "There was grave concern in the government circles of Korea that we would be sharply reducing military assistance at the very time Korea was taking a more active role in Vietnam." According to the notes of his presentation to the Vational Security Council, the Vice-President reported that korea would send troops if asked but would want assurances about their own security. In the memo of a conversation about bis meeting in Seoul, Humphrev quoted Park as salying that Korea had a "molal obligation to take up arms for any nation assaulted by communism," but that he also wanted to use a troop deplovment to stimulate his economy. "I made it quite clear to President Park and his government that there was no L.S. blank check or open ended account. I urged that he make a specific proposal to sur Ambassador so that we had something to talk about and some idea of what the Koreans wanted and needed." $3 !$

38. Brown lo Rusk, 1)ec. 2y, 1965, ibid.

39. Brackburn, Mercenares and Lyndon Johnson's "More Flags", 54-55; Summary Votes of 5joth VSC Meeting, fan. 5, 1966, LBJ Library; "Summary of Conversations with the Leadership of Japan, Philippines, Republic of China, and Korea, Dec. 28, 1965-Jan. 2, 1966, ibid.: the Vicc-P'resident to the President, Jan. 5. 1966, NSC Mectings, vol. 3, tab 37, 15. 66, box 2. NSC Meetings File, ibid; Brown 
The negotiations began in January 1966, and the Koreans once again set the agenda. Korean diplomats presented a long list of proposals for financial compensation in return for the second division. American officials back in Washington called this list "excessive." Brown rejected these items and made a counter-proposal: The Lnited States would fund additional development projects, allow only American and Korean bidding on certain Agency for International Development projects, give the Republic of Korca an additional development loan of $\$ 15$ million, and compensate ROK armed services for the cxpenses incurred in transporting the second division to Vietnam. The Koreans held firm, forcing the Lnited States closer to their position. Negotiations for the deplorment of the first division had set a precedent for the Korean position. ${ }^{4(3)}$

The negotiations concluded on March 4, when Brown sent a letter to the Korean Foreign Minister conceding most issues in Korea's favor. Although the general contents were leaked to a South Korean newspaper, scholars have never had direct access to the "Brown letter" itself. which remains classified at the time of this writing. ${ }^{41}$ The terms of the agreement, however, have recentr become available in other declassified documents, namely briefing books prepared for a visit to Washington, D.C., by Prime Minister Chong in 1968. In this eighteen-point letter, the United States agreed to do four things: (1) par the costs associated with the deployment and service of the ROK Army in Vietnam; (2) help modernize the armed forces of South Korea: (3) procure equipment, supplies, and services for use in Vietnam from Korea and Korean firms: and (4) provide economic assistance to the Republic of Korea that would foster economic development. These four main elements of the Brown letter were made public when it was leaked, leading to charges in the United States, then and now; that the Koreans were nothing more than mercenaries. A comparison of the two versions, howcver, shows that the initial account presented to the public put the agreement in a light designed to lavor the ROK govern-

(o) Rusk, Dec. 30 , 22, 1965, Kurea cables, vol. 3, box 255. horea Counury File. National Security File, ibid.

40. Brown to Rusk, Jan. 25. 1966. 1)avid E. Bell wo MaGeorge Bundy, Jan. 25. 1966, enclosed in McGeorge Bundy to Johnson, Feb. 3. 1966, ibid.

41. Blackburn, Mercenaries and Lyndon Johnson's "Wore Flags", 56-5.7. 
ment. The leaked version made it seem that the Koreans had driven a hard bargain-which led to the mercenary charge. Items that might embarrass the ROK government and qualifications on some of the more generous American concessions were absent from this rendition. Examples of embarrassing items include an American agreement to pay overseas duty bonuses and death-and-disability allowances for the Koreans serving in Vietnam. Examples of the qualifications include the U.S. agreement to purchase supplies and material from Korea, but only provided that Korea had the production capability, could meet specification and delivery schedules, had prices that were "fully competitive" with other sources in the region, and that procurement conformed to U.S. policies regulating the flow of gold. There were clearly limits to American acquiescence, but these terms were enough to win over the Koreans. ${ }^{12}$ The National Assembly approved another deployment at the end of the month, and the Ninth ROK Infantry Division, also known as the White Horse Division, began arriving in September. ${ }^{43}$

Once in Vietnam, Korean troops proved themselves an important asset. This contingent was the second largest foreign army fighting in Vietnam, behind only the Lnited States. The Koreans conducted missions along the central coast of South Vietnam. The Capital Division operated throughout the war in the Qui Nhon-Binh Khe area, while the White Horse Division was stationed along Highway 1 around the city of Ninh Hoa. The Second ROK Marine Brigade, which arrived in Vietnam with the Capital Division, was further up the coast and went on several missions with the U.S. Marine Corps. The two infantry divisions staved in Vietnam until March 1973, actually outnumbering American ground forces at that time. In 1968 Korea suffered 1,100 combat fatalities. General Wheeler, chairman of the Joint Chiefs, put these numbers into context. In a memo to President Johnson, he noted that, on a percentage basis, the Korean units suffered a combat fatality rate, 2.2 percent, that surpassed that of the South Vietnamese and was below the American rate of 2.6 percent. American generals in Saigon came to value the

42. "Korean Military Assistance to the Republic of Viet-Nam: U.S. Commitments," Prime Minister Chong Il-kwon visit, box 257, Korea Country File, National Security File, L.BJ Library.

43. Blackburn, Mercenaries and Lyndon Johnson's "More Flags", 58. 
quality of their Korean allies. In a farewell speech to the White Horse Division when he left Vietnam, Westmoreland observed, "Perhaps the best compliment to your effectiveness comes from the North Vietnamese Army and the Viet Cong by their hesitancy to engage you in battle. You have earned a reputation among communist forces as men to fear, respect... and avoid." ${ }_{44}$

Americans outside of the military stationed in Vietnam also appreciated the Korean effort. In late October and early November 1966, Johnson visited South Korea in a well-received trip. The crowd cheering the American President threw so much confetti that the secret service had to stop his car and clean the vents. The trip was mainly a goodwill tour, but Johnson had a short, substantial meeting with Park on November 1 at the Blue House, the ROK executive mansion. As host, Park started the conversation. According to the American record of this conversation, the first point he mentioned was the importance of keeping L.S. strength on the peninsula at current levels. Johnson was clearly more interested in Vietnam. He talked about how the 1930s had demonstrated the need to resist aggression. Korea, he said, making a reference to current troop deployments, was making a contribution in South Vietnam proportional to that of the United States. Johnson then coyly raised the issue of more troops. He said he was not in Korea to recruit soldiers. However, after discussing the problems Westmoreland faced in Vietnam, he said he foresaw a need for more men in Vietnam, so all concerned parties should think about how they would respond. Park made it clear that future deployments might be possible, but only after the Korean presidential election in $1967.4: 5$

Rusk and McNamara considered Korean involvement in Vietnam a great coup and later that month sent a telegram to

44. Stanton, Vietnam (hder of Battle, 272-273, 339; the ellipses are in the original document and apparcntly indicated a pause for dramatic effect. "General Westmoreland's Farewell Address to ROK 9th Division," May 21, 1968, Korean Speech, box 17, Papers of William C. Westmoreland, L.B Library; Ceneral Earle Wheeler 10 Johnson, Oct. 17, 1968. Victnam Allies 5D(3), box 91, Viemam Country File. National Security File, ibid.

45. Notes of Meeting betwcen President Johnson and President Park, Now 7, 1966, Asian Trip, Oct. 17-Nov. 2, 1966, box 48, Appointment File [Diary Backup], LBJ Library; Daily Dairy, Oct. 31, Nov. 1, 1966, folder: Oct. 17, 1960-Nov. 2. 1966, box 8, ibid.; Brown to Rusk and Mc Namara. Nov. 21, 1966, Korea cables, vol. 3, box 255, Korea Country File, Vational Security File. ibid. 
Brown instructing him to start talks on a third division. Brown refused, reminding them of Johnson's assurance to Park. More importantly, the ambassador added that "it appears to me that we are in danger of seeming to take the Koreans for granted." The United States asked for a small medical unit and got it, then for noncombat troops, and then a combat division. Less than six months later, the United States asked for and got still another division. "The Koreans will wonder when and where this will end and why others are not pressed to do likewise." ${ }^{6}$

In June 1967, as Brown prepared to leave his post in Seoul, he cabled Rusk and William Bundy, advising them that how the United States raised the issue of a third division was important. Americans should approach Park as an equal and should hold high-level briefings and consultations about developments in $V$ ietnam. The deployment of additional ROK forces should be raised only within this context. Brown reminded them that Park had said publicly that he had no intention of sending any more Koreans to Vietnam. He could reverse himself, but he had to be given good reason. Walt Rostow, the new National Security Adviser, gave the President a copy of Brown's telegram. ${ }^{47}$

The President heeded this adrice to a degree. In July 1967, in response to another Joint Chiefs request for a troop increase, he sent Washington lawyer Clark Clifford and Maxwell Tavlor, now a special presidential adviser, on an international trip to get more men. Johnson could not have sent two more influential or significant figures. Taylor had held important positions in the Eisenhower, Kennedy, and Johnson administrations. He had helped develop the strategy of flexible response of the Kennedy and Johnson administrations. Clifford was one of the most influential private citizens in America at the time, having served as special counsel to President Harry S Truman and helped implement Truman's policy of containment during the early days of the Cold War. As a successful lawyer in private practice, he advised many Democrats, particularly presidents Kennedy and Johnson. Nevertheless, the Taylor-Clifford mission failed to sway any of the nations it visited. "Even South Korea had its doubts,"

46. Ibid.

47. Brown to Rusk and William Bundy, June 7, 1967 enclosed in Wait W. Rostow to Johnson, June 7, 1967, Korea cables and memos, vol. 4. box 255. Korea Country File, National Security File, ibid. 
Clifford recalled in his memoirs. "President Park-a General who had seized power through a coup-made us sit through a dissertation on his political difficulties." His contemporary assessment of the trip was more positive. "President Park is faced with a genuine political crisis," Taylor and Clifford reported. Park told the two dignitaries that the United States could depend on him to send more soldiers when his political situation was more stable. ${ }^{+8}$ Despite their influence, Clifford or Taylor worked away from the glare of publicity, and neither held a highly visible position within the government. The fact that the two arrived in Korea clearly interested in getting additional troops also worked against them.

Although thwarted, Johnson still wanted a third division. On November 25 William Porter, the new dmerican ambassador in Seoul, cabled Washington that the political situation in Korea had become more stable in the months since the CliffordTaylor mission. The domestic problems Park had faced were over. Porter thought it was now possible to approach the Korean president about a third division. He thought the recent arrival of additional Australian and Thai troops also helped put some pressure on Korea. Each nation had increased the size of its military contingent by 2,000 men, and both were committed to further expansion in 1968. Rostow warned Johnson that the embassy expected a number of Korean requirements that would be "expensive, varied and complicated." Even though Porter cautioned that the recruitment of an additional korean division would be "an exercise with rapidly diminishing returns," Johnson decided to make the request. ${ }^{49}$ The returns might be diminishing, but a third Korean division was still cheaper and politically less painful for him than the idea of sending more Americans.

The State Department had Eugene Locke, the deputy L.S. ambassador in Saigon, visit Seoul in December on his way to the United States. Locke's mission was "to impress on Park the ur-

4ช. Enmphasis in the original. Clark Clifford. Counsel to the President: A Memoir (New York, 1991), 448-449; Clifford-Taylor Report to the President, Auy. 5, 1967, 5I)(1), box 91, Vietnam Country File, National Security File, LBJ Librars.

49. Blackburn, Mercenaries and Lyndon Johnsom's "More Flags". 158-166; Rostow to Johnson. Now. 28, 1967, William Porter to Rusk and William Bundy, Now. 25. 1967, Vietnam Allies 5 D (3), box 91. Vietnam Country File, National Security File. L.BJ Library. 
gent need for an additional Korean force in V[iet] N[am]." Locke was instructed to represent the American desire for another division as the personal view of Johnson himself. On December 7 Locke and Porter met with Park, Prime Minister Chong, and the ministers of National Defense and Foreign Affairs for over two hours. Park, according to Porter, controlled the conversation. The South Korean president said he could send a "light division" to Vietnam, but the timing and "arrangements" for such a deployment would require some work. He thought Korea could replace troops currently serving in logistical and support positions with civilians, which would make it possible to introduce more combat units into Vietnam with only a small increase in the actual number of uniformed ROK personnel serving in Southeast Asia. Over the next two weeks, American officials and Korean military officers met in Seoul to determine the necessary "arrangements." 0

The Koreans were primarily interested in building up their defenses. Since late 1966 North Korea had been sending raiding parties into the South, ambushing American and ROK units patrolling the Demilitarized Zone (DMZ) separating the two Koreas. Helping South Vietnam resist communist aggression was all well and good, but the ROK military wanted to be sure that this effort in no way jeopardized the security of Korea itself. On December 8 Porter and General Charles H. Bonesteel met with the National Defense Minister Kim and the chairman of the ROK Joint Chiefs of Staff. They learned that the Koreans wanted the United States to provide the equipment for a counter-infiltration force of eight battalions, helicopters for three new companies, enough artillery pieces to man six battalions, and a new squadron of Phantom F-4C planes. The South Koreans also wanted the immediate delivery of two destrovers that the United States had agreed to provide, plus heavy construction equipment-dump trucks, rock crushers, bulldozers, and the like-to supply five engineer battalions building the new national superhighway from Pusan at the southern tip of the peninsula to Seoul. ${ }^{51}$

50. Rusk to Porter, Dec. 5, 1967, Porter to, Rusk and William Bundy, Dec. 7, 1967 , ibid.

51. Porter and Bonesteel to Secretary of State, 1)ec. 18, 1967, Holt Funeral. vol. 3, box 461, Lot 68 D453. Executive Secretariat Conference Files. 1966i-1972, 
Park also wanted and got another high-level briefing. On December 21 he met with Johnson for lunch in Canberra, Australia. The two presidents were in the city for the funeral of Australian Prime Minister Harold Holt. For the first half of the meeting, Johnson and Park exchanged flattering remarks about each other's dependability as allies in the fight against communism. Park then explained that the North Korean attacks had complicated his ability to send a larger force to Vietnam. He had to be able to tell his public that the deployment of an additional division in no way jeopardized their security. This issue had motivated him to ask for such a large amount of equipment for use on the peninsula, rather than in Vietnam. Johnson replied that he was favorably inclined toward the Korean request, but more troops were urgently needed in Vietnam and he wanted Park to start the deployment on the strength of his reassurances. Park refused, politely. He said he needed firm American commitments, if he was to get the necessary approval of the National Assembly. Once again in a weak bargaining position, Johnson asked what Park needed. The Korean president answered that he wanted anti-infiltration equipment in Korea before he would send any more troops to Vietnam. Johnson agreed, also saying that the United States would expedite delivery of a destroyer, provide some of the equipment requested based on an assessment by the American Joint Chiefs, and keep MAP funds at current levels for Korea, even though Congress had reduced the overall amount of funding. Park then gave Johnson what he wanted. The Korean president agreed to have the new division in Vietnam by March 1, even though Defense Minister Kim said it would take until April or early May. ${ }^{52}$

North Korean infiltration and raids that had little to do with Vietnam quickly scuttled this agreement. Many observers thought the North Korean effort reflected a desire to aid their communist allies in Vietnam, citing a speech by the North's Kim Il-sung on the need for communist nations to aid Vietnam in its

Department of State Central Files, Record Group 59, National Archives, College Park, .Md. (hereatier referred to as RG; 59, NA).

52. "Notes on Conversation with President Park of Korea," Dec. 26, 1967, Holt Funeral, vol. 2, ibid.; Porter to Rusk, Jan. 15, 1968, William Bundy to Johnson, April 16. 1968, Vietnam Allies 5D(3), box 91, Vietnam Country File, National Security File, LBJ Library. 
struggle against the Cnited States-clcatr an exhortation to the communist nations of the world to send combat troops to Southeast Asia ${ }^{33}$ However, the reasons for Vorth Korean raids were local rather than international. According to Robert Scalapino and Chong-sik Lee, the attacks were attempts to induce a general insurrection similar wh that of the National Liberation Front in Vietnam that the Vorth hoped would unify the Korean peninsula. ${ }^{54}$

These small incursions were tolerable nuisances until a thirty-one-man commando unit of North Korean Army officers cut a hole through a chain-link fence in an American-monitored sector of the DMZ on January 18, 1968. The group traveled only at night, keeping to mountain ridges, and was well armed with grenades, automatic weapons, and explosives. The group's mission was simple: to assassinate Park. A secondary target was the U.S. embassy. On January 21, a thousand vards short of the Blue House, a suspicious police officer stopped the commandos at a checkpoint and exposed them. The commandos then killed a police officer, and a ruming firefight broke out in seoul as the commandos attempted to escape 5.

North Korea struck again on January 23, when it captured the L.S.S. Pueblo. Sailing off the eastern coast of the peninsula, the ship was on a mission to collect electronic signal information. A small flotilla of the North Korean Naw surrounded and boarded the ship-the first time since the War of 1812 that a foreign nawy had captured an American ship. According to Clifford, the new Secretary of Defense, news of the Pueblo almost broke Johnson. The President thought the seizure of the ship was a communist effort to draw American attention from Vietnam and to overextend U.S. military resources with another engagement. ${ }^{56}$

American officials worried that ROK leaders were prepared to launch a second Korean War in retaliation for these attacks.

53. Vandon E. Jenerette, "The Forgouen DMZ," Wilitury Review. 58 (May 1988), 32-43.

54. Robert A. Scalapino and Chong-sik i ee, Communism in Korra (2) vols., Berkeley, 1972), 1: 638fin-639fn, 647-65:3.

55. Chosun llbo, Jan. 23, 1968; Military Assistance Command to foint Chicef of Staff, Jan. 27, 1968, Korea-Pueblo Incident military cables, wol. 1. box 263-264, Korea Country File. National Security File, I.BJ l.ibrary.

56. Clifford. Counsel to the President. 466. 
On January 24. Ambassador Porter met with an enraged Park. In Porter"s words, Park "vehemently" demanded a military response. He suggested either an atack on the base of the commando unit that had conducted the Blue House raid or a strike against North Korean air and naval stations on the east coast. The ROK trmy would not take anv unilateral action, for now; but Park wanted Porter that retaliatory raids were inevitable. He also expressed irritation that the United States showed more concern about the Pueblo than the attacks along the DMZ or the attempt to assassinate him. In a cable to Nashington. Porter commented, "I think we have what we want trom him in the way of assurance, but if there is another incident all bets are ofl."

Although weil aware of the importance the fohnson administration placed on Vietnam, Porter warned that it would be unwise to push for the third division. The ROK Joint Chiefs had just asked General Bonesteel, Commander-in-Chief of the Lnited Nations Command, to begin planning for the return of Korean forces in Vietnam. The staff of the L.S. cmbassy believed this was normal contingency planning, but the request demanded caution. "For L'S. to press ROKs at present juncture might well result in decision against dispatch, which remains quite reas[ona]ble in my opinion provided there is a satistactory outcome to Pueblo North Korean armistice violation problem." 58

Officials in Washington, D.C., worried about these problems in Korea and their impact on troop deplowments for Vietnam. A joint nessage from the Defense and State departments gave Porter clear instructions: "You should convey to Park in whatever words you find appropriate that loose talk in korea about pulling back some forces from Vietnam has not, rle]p[ea]t, not been well received here." The State Department believed that anv removal of Korean units from Vietnam or a reluctance 10 send more soldiers would be a North Korean victory. Samuel D. Berger, Assistant Secretary of State and former ambassador to South korea, reasoned, "It follows from this thread of argument that when things settle down in South Korea, Pa[r]k could win a

57. Porter to Rusk, Jarl. 24, 1968, Korea memos and cables, vol. 5, box 255. Korca Country File, National Security File, L.BJ Library.

58. Air Force Chief-of-Staff to subordinate commands, Jan. 29, 1968, KortáPueblo Incident militarv cables, vol. 1, box 263-264. ibid.; Porter to Rusk, Jan. 30. 1968, Victnam allies 5D(3), box 91, Vietnam Country File, Vational Security File. ibid. 
moral and psychological victory over Kin ll-sung, show his contempt for Kim, and confidence in himself and his countr's, if he could announce that additional forces will be sent to VietNam." ${ }^{99}$ At a February 7 meeting of the National Security Council, General Wheeler warned: "The problems in Korea are such that it will be hard to get the South Koreans to even send the light division they had promised." ${ }^{60}$ Yet, the third division became even more important when Westmoreland requested another increase in manpower, forcing a profound debate within the U.S. government about American policv toward Vietnam."il

If troops were necessary, Lyndon fohnson preferred to use foreign ones to avoid some of the domestic ramifications that an increase in U.S. troops would entail. Two dav's later at another NSC meeting, the President said, "Let's assume we have to have more troops. I think we should now tell the allies that we could lose Southeast Asia without their help. The first to tell is Park. Tell him that none of us want defeat. If it takes more men to avoid defeat let's get them." McNamara, who was still attending NSC meetings at this time, cautioned Johnson that this might not be feasible. "One thing we have to do is put more support in Korea," he said. ${ }^{62}$

American hopes for a third division ended on March 22. The L.S. embassy in Seoul reported that Foreign Minister Chio had announced that South korea would not send anv more troops to Vietnam. ${ }^{63}$ The Lnited States would have to resolve the manpower problem without Korean assistance.

When the Republic of Korea sent its soldiers to scre in Vietnam, it did so because it considered the action to be in its best interests. South Korea supported the L.S. effort in Vietnam but required significant compensation and high-level consultation with American officials before it would deploy its troops in

59. Joint State-Defense Message, Feb. 7, 1968, Samuel Berges 10 Embassv in Seoul, Feb. 12, 1968, unmarked folder, hox 2955. tile 3:-36. Central Foreign P'olic Files, $1967-1969, \mathrm{RG} 59, \mathrm{NA}$.

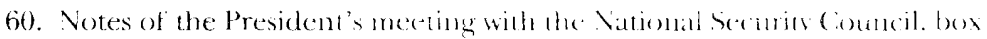

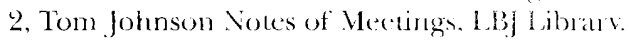

61. Clitford. Connel to the President, 176-486, t92-501.

62. Tom Johnson to Lundon Johnon, Leb. 9, L968. Varch 31 speech, vol. T. box 49, NSC Histories, Natunal Securin File, LBJ Library.

63. Porter to Rusk. March 29. 1968. Korea-Pucblo Incident military cables, vol. 2, box 261-262, Kored Country File, National Security File. ibrid. 
Southeast Asia. This gesture was an effort to keep U.S. troops on the Korean peninsula, and only when North Korea began a series of raids and attacks across the $\mathrm{DMZ}$ did ROK leaders decide against sending any more divisions overseas. These attacks clearly changed South Korean priorities. Although the Republic of Korea still supported the American effort in Vietnam and kept its troops in that country, its interests had changed and prevented the introduction of any new units. These facts show that Koreans fought in Vietnam because it was in South Korea's national interest, not as a way to make a profit for the Republic. 